\title{
Molecular and Virological profile of Professional Sex Workers (PSW) and their Partners at the beginning of ARV Treatment at IST Matonge in Kinshasa
}

\author{
Erick Ntambwe Kamangu ${ }^{1,2 *}$, Berry Ikolango Bongenya ${ }^{2}$, Ben llunga Bulanda ${ }^{2}$, Alex Albati Kalume ${ }^{3}$, \\ Pablo Menayaku Mabanza ${ }^{3}$ and Richard Lunganza Kalala ${ }^{1}$ \\ ${ }^{1}$ Molecular Biology Unit, Department of Basic Sciences, Faculty of Medicine, University of Kinshasa, Kinshasa, Democratic Republic of Congo (DRC) \\ ${ }^{2}$ Research Group "Focus HIV/AIDS", Kinshasa, Democratic Republic of Congo (DRC) \\ ${ }^{3}$ Center of Treatment for Sexually Transmitted Infections and HIV/AIDS of Matonge (IST-Matonge), Kinshasa, Democratic Republic of Congo (DRC)
}

*Corresponding author: Erick Ntambwe Kamangu, Service of Molecular Biology, Department of Basic Sciences, Faculty of Medicine, University of Kinshasa, Kinshasa-Democratic Republic of Congo, Tel: +243(0)815401600; E-mail: erick.kamangu@unikin.ac.cd

Copyright: C2018 Kamangu EN, et al. This is an open-access article distributed under the terms of the Creative Commons Attribution License, which permits unrestricted use, distribution, and reproduction in any medium, provided the original author and source are credited

Received date: April 10, 2018; Accepted date: May 05, 2018; Published date: May 14, 2018

Citation: Kamangu EN, Bongenya BI, Bulanda BI, Kalume AA, Mabanza PM, et al. (2018) Molecular and Virological profile of Professional Sex Workers (PSW) and their Partners at the beginning of ARV Treatment at IST Matonge in Kinshasa. J HIV Retrovirus. Vol. 4 No.2:10

\begin{abstract}
Background: Professional Sex Workers (PSW) and their partners are considered as vulnerable populations at high risk of transmission for Sexually Transmitted Infections (STIs) as well as infection with the Human Immunodeficiency Virus (HIV).
\end{abstract}

Objective: The objective of this work was to determine the molecular and virological profile of PSW and their clients at the beginning of Antiretroviral Treatment (ART) followed at the IST Matonge center in the city of Kinshasa.

Methods: Twenty (20) subjects diagnosed HIV-1 positive by serology at IST-Matonge voluntarily participated in this work. This is the PSW and their partners, all aged over 18 and naive ART. Blood samples were collected in $5 \mathrm{ml}$ tubes with EDTA anticoagulant. After extraction of the RNA from the plasma collected using the QIAGEN RNA kit, a Quantitative Real-Time PCR (qPCR) was used for the determination of the Viral Load (VL). Then Reverse Transcriptase PCR (RT-PCR) and Nested PCR were used to amplify the regions of interest on Protease and Reverse Transcriptase for subsequent sequencing by the Sanger method.

Results: Twenty (20) patients were included in this work. Forty-five percent (45\%) of the patients were women. The median age was 43 years. The median value of the $V L$ of the included patients was $5.53 \log _{10}$ RNA copies $/ \mathrm{ml}$. The dominant subtype in this population was $\mathrm{K}$ with $25 \%$.

Conclusion: Proffesional sex workers and their partners remain a population at risk for transmission of HIV infection which has a particular molecular profile and most begin treatment with a poor viral prognosis of treatment.
Key words: Molecular profile; Virological profile; Sex workers; HIV/AIDS; Kinshasa

\section{Introduction}

Professional Sex Workers (PSW) and their partners are considered as vulnerable populations at high risk of transmission for Sexually Transmitted Infections (STIs) as well as the Human Immunodeficiency Virus (HIV) infection [1]. The prevalence of HIV infection in the PSW population is higher than in the general population [2]. Evidence continues to show that unprotected and tariffed sex is a significant factor in maintaining the HIV epidemic in several countries in sub-Saharan Africa [3]. The scale of this public health problem calls for on-going prevention, effective treatment and particular follow-up of patients in this vulnerable group [4].

In the Democratic Republic of Congo (DRC), few studies describe the HIV epidemic in regard of this targeted population. Hence the objective of this work was to determine the molecular and virological profile of PSW and their partners at the beginning of Anti-RetroViral Treatment (ART) at the Center of Treatment for Sexually Transmitted Infections and HIV/AIDS of Matonge (IST Matonge) in Kinshasa.

\section{Methods}

\section{Study population}

Twenty (20) subjects diagnosed positive for HIV-1 by serology at the Center of Treatment for Sexually Transmitted Infections and HIV/AIDS of Matonge (IST-Matonge) voluntarily participated in this work. These were the PSW and their partners all recruited in Kinshasa. All patients were aged over 18 years and naive ART in the period from November 08, 2013 to February 14, 2014 without any discrimination. IST-Matonge has an annual average of 40 patients followed for HIV infection per year. 


\section{Collection of samples}

Blood samples were collected in $5 \mathrm{ml}$ tubes with EDTA anticoagulant from the elbow crease vein after patient consent. The collected blood was centrifuged at $3000 \mathrm{rpm}$ for $10 \mathrm{~min}$ to obtain clear separation in 3 phases. Plasma thus obtained was used for the determination of Viral Load (VL) and sequencing.

\section{Amplification and Sequencing}

After extraction of the RNA from the plasma collected using the QIAGEN RNA kit [5], a Quantitative Real Time PCR (qPCR), previously described $[6,7]$, was used for the determination of VL. A Reverse Transcriptase PCR (RT-PCR) and a Nested PCR were used to amplify the regions of interest on Protease and Reverse Transcriptase for subsequent sequencing. All PCRs were performed under previously described cycle and temperature conditions $[6,7]$. For sequencing, each sample was amplified on Protease and Reverse Transcriptase regions in both sense and antisense [8].

The amplified fragments were sequenced by the Sanger sequencing method [8]. The pairing of the obtained fragments (sense and antisense) was done with the Vector NTI Advance 11.5 software (Invitrogen, Life Technologies) and compared with different databases for the identification of HIV type 1 subtype [8].

\section{Results}

Twenty (20) patients were included in this work. Forty-five percent $(45 \%)$ of the patients were women and $55 \%$ were men; giving a sex ratio of 1:1. The median age was 43 years within the range of 20 to 60 years.

Table 1 Molecular and virological epidemiological profile of professional sex workers (PSW).

\begin{tabular}{|c|c|}
\hline Characteristics & Patients $(n=20)$ \\
\hline \multicolumn{2}{|l|}{ Sex } \\
\hline Female & $9(45 \%)$ \\
\hline Male & $11(55 \%)$ \\
\hline \multicolumn{2}{|l|}{ Age (years) } \\
\hline Interval & $20-60$ years \\
\hline Median & 43 years \\
\hline $18-25$ & $3(15 \%)$ \\
\hline $26-35$ & $3(15 \%)$ \\
\hline $36-45$ & $4(20 \%)$ \\
\hline $46-55$ & $7(35 \%)$ \\
\hline $56-65$ & $3(15 \%)$ \\
\hline \multicolumn{2}{|c|}{ Viral Load $\left(\log _{10}\right.$ RNA copies $\left./ \mathrm{ml}\right)$} \\
\hline Interval & $1.35-7.95$ \\
\hline Median & 5.53 \\
\hline
\end{tabular}

\begin{tabular}{|c|c|}
\hline \multicolumn{2}{|c|}{ Subtypes of HIV } \\
\hline A & $3(15 \%)$ \\
\hline C & $2(10 \%)$ \\
\hline G & $3(15 \%)$ \\
\hline H & $1(5 \%)$ \\
\hline J & $2(10 \%)$ \\
\hline K & $5(25 \%)$ \\
\hline U & $2(10 \%)$ \\
\hline CRF02_AG & $2(10 \%)$ \\
\hline
\end{tabular}

The median value of the $V L$ of the patients included was 5.53 $\log _{10}$ RNA copies/ml (340 000 RNA copies/ml). The minimum and maximum values were respectively 1.35 and $7.95 \log _{10}$ RNA copies/ml (22.28 and 88, 850, 000 RNA copies/ml). Seventy-five percent $(75 \%)$ of patients begun treatment with a VL greater than $5.00 \log _{10}$ RNA copies/ml.

The dominant subtype in this population was $\mathrm{K}$ in 5 patients (25\%), followed by subtypes $A$ and $G$ in 3 patients each (15\%), subtypes $\mathrm{C}, \mathrm{J}$ and $\mathrm{U}$ in 2 patients each (10\%), subtype $H$ in 1 patient (5\%) and CRF02_AG in 2 patients (10\%) (Table 1).

\section{Discussion}

The objective of this work was to determine the molecular and virological profile of Professional Sex Workers (PSW) and their partners infected with HIV-1 who were eligible for initiation of Antiretroviral Therapy (ART) followed in the Center of Treatment for Sexually Transmitted Infections and HIV/AIDS of Matonge (IST-Matonge) of Kinshasa. The study population was composed of $45 \%$ female and $55 \%$ male, a sex ratio of $1: 1$. The median age was 43 years and the most represented age group was 46 to 55 with $35 \%$ of patients. Different studies have shown younger age groups for the PSW population for Kinshasa $[9,10]$.

The median value of the viral loads of the patients included was $5.53 \log _{10}$ RNA copies/ml (340 000 RNA copies/ml). The minimum and maximum values were respectively 1.35 and 7.95 $\log _{10}$ RNA copies/ml (22 and 88, 850, 000 RNA copies/ml). Seventy-five percent (75\%) of patients started ART with a VL greater than 100,000 RNA copies/ml or $5.00 \log _{10}$ RNA copies $/ \mathrm{ml}$. Several studies had shown that a VL greater than 5.00 $\log _{10}$ at the beginning of ART is a poor prognosis for starting treatment [11-13]. Hence $75 \%$ of this population starts treatment with a high probability of being in treatment failure. This problem has also been raised by another study in our community that mentions the delay in the management of patients [14]. This late treatment soon becomes a condemnation for patients who therefore have poor support for ART. This is often the result of late diagnosis of HIV by the population.

The dominant subtype in this population was $\mathrm{K}$ in 5 patients (25\%), followed by subtypes $A$ and $G$ in 3 patients each (15\%) subtypes $\mathrm{C}, \mathrm{J}$ and $\mathrm{U}$ in 2 patients each (10\%), subtype $\mathrm{H}$ in 1 patient (5\%) and CRF02_AG in 2 patients (10\%). This heterogeneous distribution of strains in this study population 
was different from the distribution of strains for the city of Kinshasa [8]. For a heterogeneous population of Kinshasa, according to recent publications, subtype $A$ was still the majority with $22.9 \%$, followed by CRF02_AG with $11.1 \%$, subtypes C, G and $\mathrm{K}$ with $9.8 \%$, and subtypes $\mathrm{D}$ and $\mathrm{H}$ with $7.8 \%$ [8]. Especially for the Funa district where the study center is located, subtype $A$ was dominant with $32 \%$, followed by subtypes $C$ and $\mathrm{K}$ with $15 \%$, CRF02_AG with $10 \%$, subtypes $G$ and $H$ with $8 \%$, J and $U$ with $5 \%$ and $U$ with $2 \%$ [15]. The molecular profile of the IST-Matonge is different depending on the peculiarity of its patients compared to the general population. This different molecular profile further demonstrates the specificity of HIV infection and the importance of assiduous management.

These data present the diversity of the epidemiology of Type 1 HIV infection in Kinshasa from the different infecting strains that circulate in the city along different lines of propagation.

\section{Limitation of Study}

Due to different constraints, the center receives only 40 patients per year thus the small sample size during the inclusion period. However, this does not remove the pertinence of the results. The profile of this targeted population is different due to sexual exposure.

\section{Conclusion}

Professional Sex Workers and their partners remain a population at risk for transmission of HIV infection which has a particular molecular profile. Most of them begun ARV treatment with a poor viral prognosis of treatment. This population presents a particular molecular profile and most begins ART with a bad prognosis.

\section{Conflict of Interest}

The authors declare that they have no conflicting interest.

\section{Thanks}

The team thanks all the Professional Sex Workers and their clients and partners followed at IST-Matonge who agreed to participate to the study.

\section{References}

1. https://www.unodc.org/documents/hiv-aids/publications/ JC1696_UNAIDS_GuidanceNote_HIVandSex-Workers_French.pdf

2. (2014) Ministère du Plan et Suivi de la mise en œuvre de la révolution de la modernité et Ministère de la Santé Publique,
République Démocratique du Congo. Rapport synthèse de I'Enquête Démographique et de Santé (EDS), 2013-2014.

3. Chen L, Jha P, Stirling B, Sgaier SK, Daid T, et al. (2007) Sexual risk factors for HIV infection in early and advanced HIV epidemics in sub-Saharan Africa: Systematic overview of 68 epidemiological studies. PLoS One 2: e1001.

4. Mamadou S, Laouel KA, Rabiou S, Aboubacar A, Soumana O, et al. (2006) Prévalence de l'infection due au VIH et de cinq autres infections sexuellement transmissibles chez les professionnelles du sexe à Niamey, Niger. Bull Soc Pathol Exot 99: 19-22.

5. QIAGEN (2010) QIAamp ${ }^{\circledR}$ RNA Mini and Blood Mini Handbook. 3rd Edn, pp: 27-29.

6. Kamangu EN, Chatte A, Boreux R, Kalala LR, Mvumbi LG, et al (2014) Mise en place d'une PCR Quantitative Temps Réel pour la détermination de la Charge Virale VIH à Kinshasa. Journal de Recherche BioMédicale 1: 7-12.

7. Kamangu EN, Chatte A, Boreux R, Kalala LR, Mvumbi LG, et al. (2014) Implementation of an in-house quantitative real-time PCR for determination of HIV viral load in Kinshasa. Open Access Library Journal 1: 1-5.

8. Kamangu EN, Chatté A, Susin F, Boreux R, Kalala LR, et al. (2015) Genetic diversity and antiretroviral drug resistance among drugnaïve HIV type 1 infected patients attending clinics in Kinshasa, Democratic Republic of Congo. J HIV AIDS 1: 1-6.

9. Bongenia $\mathrm{BI}$, Bulanda $\mathrm{BI}, \mathrm{Bukongo} \mathrm{NR}$, Okonda OM, et al. (2018) Prévalence des Infections Opportunistes chez les Professionnelles de Sexe et leurs Clients vivant avec le VIH sous ARV au Centre ISTMatonge de Kinshasa. Under press

10. Bongenia $\mathrm{BI}$, Bulanda $\mathrm{BI}$, Botomuito HT, Kamangu EN (2018) Prévalence des Infections Opportunistes chez les Professionnelles de Sexe et leurs Clients vivant avec le VIH sous prophylaxie Cotrimoxazole au Centre IST-Matonge de Kinshasa. Under press.

11. Wateba INM, Patassi AA, Balaka A, Tidjani O (2013) Viral characteristic of HIV infected patients Naif of anti-retroviral therapy with CD4+ T lymphocytes rate greater than $350 / \mu \mathrm{L}$ of Blood in Lomé, Togo. World J AIDS. 3: 364-366.

12. Egger M, May M, Chêne G, Phillips AN, Ledergerber B, et al. (2002) Prognosis of HIV-1-Infected patients starting highly active therapy: A collaborative analysis of prospective studies. Lancet 360: 119-129.

13. Phair JP, Mellors JW, Detels R, Margolick JB, Munoz A (2002) Virologic and immunologic values allowing safe deferral of antiretroviral therapy. AIDS 16: 2455-2459.

14. Kamangu EN, Bulanda BI, Bongenia BI, Botomwito HT, Mvumbi GL (2015) Virological profile of patients infected with HIV starting antiretroviral treatment in Kinshasa. Open Access Library Journal 2: e1564.

15. Kamangu EN, Bulanda $\mathrm{BI}$, Bongenia $\mathrm{BI}$, Botomwito $\mathrm{HT}$, Mvumbi $\mathrm{GL}$, et al (2018) Molecular epidemiological profile of HIV type 1 infection in Kinshasa treatment-naïve patients. Under press. 